\title{
7. INTEGRALITY OF MUSICAL EDUCATION LESSON - PRAXEOLOGICAL PERSPECTIVES
}

\begin{abstract}
One of the most important goals of modern pedagogy is to identify the educational potential, to define ways of asserting man as a subject of cognition, communication and creation. This article investigates the praxeological aspects of the musical education lesson, expressed through the concept of integrality. The issue of integrality is one of the key concerns related to man's cognition of reality: the integrality of internal and external phenomena (cognitive and affective); the logics that moves the processes of cognition; the categories of the integral system, divided into partitioned / whole and others. From this perspective, for a fundamental change in education, a global and unitary vision is needed on the concept of integrality and on the activity of personality formation and development.
\end{abstract}

Key words: praxeology, integrality of the lesson, emotional, rational

\section{Introduction}

In the third millennium, the millennium of global change we are witnessing, both in society and in educational practice, many events that ensue at an accelerated pace as well as a series of global problems. Simultaneously with social change, there takes place a shift in the contemporary man's hierarchy of values. The indispensable link between nature and society is self-evident: the formation of the concept of world integration is a dominant one in education. Integration stimulates multi-faceted perception of phenomena, forming an integral vision of the Universe.

The Universe is a system whose elements are in close connection. We know that the biosphere is an integral system, and all living bodies are elements of this system. Our vision of the system with its components is different and depends on the perspective from which the world is viewed. Over the course of a few millennia, man creates his own history, his own culture - a „,second nature”, is the creator of a new space by knowing and changing the world.

We view reality from another point of view: everything moves, everything vibrates in it. We understand that life integrates various components: molecules, cells, organisms, etc. Life is a perfect matter, which we call the soul - the soul is „the holy holiness” of our hearts. All matter involves itself in a systemic rotation, eventually forming a whole with a living breath, which is the Genesis of the World - the Infinite.

\section{The Concept de integrality in pedagogical sciences}

The modern society, dominated by permanent and profound transformations, imperiously demands new ideas and actions. The school, the students, and the teacher stand ahead of these changes. In this context, it becomes imperative that students learn to learn - so that they can integrate into

\footnotetext{
${ }^{263}$ Lecturer, Doctoral Candidate, „Alecu Russo” State University from Bălţi, Republic of Moldavia, email: caligamarina@inbox.ru
} 
society. "To be an integral person means to have vision, passion, discipline, consciousness, etc.," claims St. R. Covey [3, p. 338]. This skill, which defines the spiritual code of each individual, is generated by the amalgamation of the constitutive components of integrality: talent, passion, the need to manifest and relate, consciousness, etc.

Professor I. Gagim investigates: "Man, as an integral and integrative being, the inner man (the intimate universe of man) as the essence of the human being becomes the main research subject of all fields of knowledge" [5, p. 3]. In this regard, the psychologist I. Negura argues that "Human knowledge has become a very tempting and up-to-date research issue today, because man can improve his being and enhance virtues only by better knowledge" ([Apud: 6, p. 9]). Therefore, over the millennia, in the process of knowing and changing the world, man discovers himself.

Man's knowledge is determined by his tendency to understand the world around him as well as his place in this world. The given activity is based on the emotional perception and rationality: the tendency towards rationalism and the awareness of the emotional experience. Man desires to solve the homo sapiens mystery, hence the man's thirst for knowledge and self-knowledge, the desire to know the new and the integration of this new with the mysteries of the past. In the context of the interaction between man and the world around us, taking into account the indissoluble link between Creator and Creation, we draw the conclusion about the level of spiritual fertility of man, of the "spiritual humus", determined by the influence of such phenomena as education and human development.

From the perspective of integral education and the concept of permanent learning with the complex and integrated nature of the problems faced today by humanity, among which we highlight globalization, information explosion, population migration, etc., education is called upon to bring its contribution to solving these factors in the formation and development of the human being. From this perspective, for a fundamental change in education, a global and unitary vision is needed on the concept of integrality and on the activity of personality formation and development. The thoughtful research of this problem demonstrates the human demand for fluidity of thought and action, flexibility, i.e. the ability to adapt to different situations, find unusual solutions, abstraction and synthesizing skills, attitude of redefining and transforming the function of an object in another, etc.

Analyzing the pedagogical sciences of the end of the last century, one may observe an immense number of approaches, which complement the old model by analyzing and reflecting on the possible integration of the current orientations. The complex nature of integrality continually seeks researchers from multiple scientific fields, becoming an obvious necessity. The idea of integrality and integration is quite old; the last decades mark a notable increase in integrative phenomena. Currently, integrality is a global trend that characterizes systemic processes that take place in science, art, culture. We approve of the idea "the creation of the full man can be multidimensional and 
developed on all the axes of his becoming - biological, psychological, cultural, social etc.” [8, p. 166]. Hence the significance of the concept of integrality, based on the evolution of the fields of science, on the global growth of knowledge and the requirements towards them.

Integrality, integrity, integration, integrate, etc. are just a few notions commonly used in contemporary pedagogy and are of interest to the researched problem. Integrality from French integralite - state, condition of being whole, complete; the ability to build a whole, a system; the process that adds the parts of the system into a whole. Integrity - the property of being integral; (from Latin integratio - "restore, evoke, complete"), which can be divided into small elements, but these elements come together, integrate, forming a whole of its parts. Integration - the action of (to) integrate and its result. Integrate - to include, to englobe etc. Integrant - a part that necessarily forms part of a whole [2, p.497].

The concept of integrality has a fairly long history. The issue of integrality is one of the key issues related to man's cognition of reality: the integrality of internal and external phenomena, the logics that moves the processes of cognition, the categories of the integral system, divided in part / whole and others. Namely in man, as in an integral system, nature integrates such a mechanism: gaze, face mimics, cognitive processes - all of which have genesis in nature. Human reason, consciousness, motivation, sensation, will, and other actions are simply different possibilities of knowing the 'part' of the 'whole'.

The dialectics of whole - part categories articulates an integrating character through: the movement of knowledge; embodying units and diversity, which usually start from something unitary; integral moves to systematization by parts / elements; finishes this circle of knowledge in the form of an integrator system, etc. This proves that nature has developed man's thinking, reaching the highest levels, through qualities of self-knowledge and self-development, placing the activity of the individual at the center of any kind of knowledge.

Following the research of the philosophical writings of antiquity, it was found that this phenomenon acted on systemic structures. The integral nature of system elements at process level has been called holism (Greek ö $\lambda$ o $\zeta$, whole, integral) - the theory that emerges from integrality. From an ontological perspective, holism is a philosophical concept that interprets the thesis of integrity to the sum of its parts, considering it as an "integrating factor" of the world. With L. van Bertalanffy, the principle of holism is raised to the level of a general theory of systems [1].

The holistic perspective has found numerous applications in economics, sociology, philosophy, culture, etc. In the philosophy of culture, the first to address this problem is J.Smuts [13]. He researched holism as an independent systemic theory, whose elements are in permanent integrality. The concept of integrality in the Kantian vision is researched by dividing the parts of a certain domain of cognition, to make it representative as a system [10, p. 197]. It means that all elements that integrate into a system form a process. 


\section{Praxeological perspectives of lesson integrality}

One of the most important opportunities of modern pedagogy is to identify the potential of education, to define ways of asserting man as a subject of cognition, communication and creation. All involve the development of a personality endowed with independent thinking, prone to self-training, creative activities, and maximum talent. However, the focus of the contemporary educational process on developing the individual's capacities to approach the objective reality in a creative and integrated manner, on his rational and emotional accumulations, increasingly contradicts the "rational supremacy" of education.

In general, the outcome of school education is effectiveness of the thinking process, students' operating with terms and notions, performing and analyzing logic operations, less frequently, attention being paid to the emotional-emotional aspect. Thus, in the educational process, it is necessary for the teacher to harmoniously combine scientific and artistic knowledge. As in practical or methodological terms, the theoretical dimension of this subject is widely debated, there are several loopholes, more specifically, in the sense of the music teacher's conception of the lesson in such a way as to obtain integrating elements of rational and emotional in its content and structure.

Explored from antiquity, for which the inherited traits, the innate ideas were stored in the human reason of God Himself, it became known that human beings are not born equally endowed with psychophysical possibilities and that they have no identical conditions of development and manifestation. The human psyche is a systemic construction through mental processes and qualities. Moreover, two fundamental aspects of mental activity can be distinguished: the first, the rational and the second, the emotional: the mind and the sense, the brain and the heart, the reflexive and the affective sphere. The human brain has thinking centers, a cognitive area and an emotional area. It has already become axiomatic that the rational and the emotional part are related to the activity of the two cerebral hemispheres. Thus, the left hemisphere is responsible for the reflexive, rational aspect, and the right hemisphere for the affective and emotional.

The problem of the integral development of the rational and emotional - the cognitive and affective has been a concern for scholars over several decades. They are trying to demonstrate which of them is primary and which is secondary. These two contradictory categories integrate through two warning systems at all stages of the individual's formation / development. The concept of educational activities is based on a competent approach, focusing on creative, free thinking, integrating in life practice theoretical and practical knowledge and skills. From the above, we conclude that man's relationship with art has a defining character, integrating the entire system of relationships, stimulating the purposes of cognition and the creative ones, integrating the interest with the needs, etc.

The idea that people are born with a general, inborn, "more or less developed" cognitive faculty has long been under investigation. Every human 
being is born and matures in such a way that it has some relatively common psychophysical peculiarities, but also some special psychic peculiarities, which constitute the individuality of each one.

J. Piajet's theories of cognitive development are an undeniable contribution to the theoretical foundation of learning strategies in a collaborative context. The learning process is seen as a progressive "accumulation" of knowledge in the relationship between the current level of cognitive development and the task that is the subject of learning [11]. On affective development, the integration of man into the surrounding world through various activities contributes to the formation/development of the values of the emotional perception of the world through spiritual values - at different levels of knowledge about it.

H.Gardner, investigating the formation/development of the personality, states: "The intellectual level of the student is studied as a bio psychological potential, which according to the environment is formed as a complex system, integrating real knowledge with affective ones” [7, p.33-34]. The theoretical model of this development proves the integrated pedagogical action through a cognitive and affective development of the student's abilities, and the capacities are not only the innate ones but also the ones that are constantly educated / cultivated. A characteristic of this training is the psycho-physiological development of the child as a pre-requisite for musical education.

Based on research results on the asymmetry between the celebrated hemispheres, the problem has been the subject of research for many scientific fields such as psychology, psychophysiology, musicology, etc. By investigating the functions of the right and left hemispheres of the human brain, it has been proven that the right hemisphere processes not only affective but also logical information. The scientist J. Polich argues: "The right hemisphere mechanism processes the information simultaneously: the difference in the functioning of the hemispheres and the different types of thought attests not the character of the matter addressed, but the way of its integration into activity" [12, p. 297]. Al. Einstein, who has integrated into his research the art of science - physics with music - is of the opinion: "In a scientific reasoning, the artistic element is obligatory present: the integration of science with art prepares a systemic thinking capable of conquering the truth" [4, p. 45].

The great Leonardo da Vinci, painter and sculptor of the Renaissance age, mathematician and anatomist, skillful musician, sought perpetual ways of integrating the arts, not only as a theorist, but also as a practitioner. Current research in the field of psychology and the human brain science proves the existence of two fundamentally different thoughts. In the cells of both cerebral hemispheres we observe capabilities for one activity or another. The left hemisphere organizes any verbal or imaginary information, analyzing and structuring the capacity of logical, rational development. The information processed in the left and right hemispheres forms the strategy of the information elements and thus systemizes the asymmetric system of the inter-cerebral brain function. The right hemisphere imaginatively integrates information, but the left hemisphere systemizes and structures it. The dynamics of the perceptual act in 
itself carries the mark of the general psychophysiological particularities as well as of the special ones, specific to the individual, features of temperament, skills, attitudes, etc. At any moment, perception is outlined as a dynamic, synthetic phenomenon that integrates with the other components, the sides of the personality as a whole.

In a general functional sense, perception appears not only as an image of the reflected object but also as a 'mirror' - a matrix of the personality of the subject perceiver, as a specific way of manifesting it in its relations with the world. In the perception, as in other psychic processes, such as thinking, imagination, memory - man defines himself, reveals the content of his personality (the level of general and artistic intellectual development, intentions in forming attitude, the desire to manifest through attitudes - in other words, student's attitude by perceiving the sound message, etc.). Many researchers argue that the development of the thinking strategies of both cerebral hemispheres should not dominate any of them, but on the contrary, the activities must be designed in such a way as to contribute to the development of both the left and right hemispheres. In this way, two blocks of integrative educational activity are distinguished: the cognitive block and the affective block.

Through these blocks we witness the integrality of the two directions of student's formation/development: integrality of the cognitive with the affective. It systematizes the cognition and imaginative-artistic factors of the student's activity through perceptual processes. Relying on the scientists' ideas, we assert that the integrality of the cognitive with the affective allows us to perceive the "surrounding world picture" - integral. The tendency to break the gap between these fundamental aspects as: logical-gnoseological and artistic-aesthetic, will contribute to a deep perception of the links between the surrounding life and the process of its cognition, the formation of an integral personality. Researching science as an art and art as a science through two directions of cognition, L. Vygotsky argued: "art is thinking, but a special type of thinking. The purpose of art is to perceive and to know things through the integral activity process" [p. 67].

Based on these assertions, we highlight the theses related to the field of psychology, through which the contents of the artistic domain closely integrate with the form, explaining these links as mechanisms that integrate art with perception, sensation, attitude, etc. Therefore, any art creation gives us impulses to perceive and know things, whereas the inner personality perceives creation through different perceptive qualities. The tendency to integrate these two extents of cognition: affective with cognitive contributes greatly to the formation / development of personalities.

\section{Conclusions}

Based on the scientific research of the physiologists, related to the interhemispheric brain asymmetry, it is concluded that a harmonious development of the child can be achieved only in the case of a good functioning of both hemispheres. Therefore, the integrality of the emotional-artistic and the 
logical-scientific contents in the educational process contributes to the pupil's formation / development. Obviously, if the artistic image turned into a language of logics, science would replace art altogether. A reverse hypothesis: if the artistic image would not be explained by logical language, there would be no art theory. However, the artistic image cannot be fully researched only by logical processes, it is here that sense integrates and complements this connection: emotional-rational and logical-imaginative.

The synthesis of arts and logics is confirmed by the psychological and psychophysiological peculiarities of man. By investigating these categories, we got support from the idea that these are not only a reflection of reality but also an essential form of understanding the world - transforming it from one hypostasis to another. The main purpose is human activity. Therefore, the logic integrated with the artistic becomes a reflection of this integral transformation. Artistic thinking is a complex psychological structure that determines artistic creation and artistic perception through musical-didactic activities. It means that artistic thinking is a process that integrates into the educational processes by content and form, the result of which is arts. From the above-mentioned theses, we conclude: cognitive-affective integrality is the concept that integrates the Music Education lesson from praxeological perspectives. This concept aims at following the musical-educational process from a praxeological point of view in the formation/ development of the pupil's cognitive-emotional integrality at the Music Education lesson.

\section{Bibliography}

1. Bertalanffy, L., (1972), General System Theory. Foundations, development, applications, Braziller, New York.

2. Coteanu, I., Seche L., (1998), Dicţionarul explicativ al limbii române. Ed.a II-a, Ed. Univers Pedagogic, Bucureşti.

3. Covey, S. (2005), Eficienţa în 7 trepte sau un abecedar al înţelepciunii, Editura ALL, Bucureşti.

4. Enştein, Al., (1965), Fizica și realitatea, Moscova.

5. Gagim, I., (2004), Fundamentele psihopedagogice şi muzicologice ale educaţiei muzicale. Referat ştiinţific al tezei de doctor habilitat în baza lucrărilor publicate în pedagogie, Chişinău.

6. Gagim, I., (2003), Dimensiunea psihologică a muzicii, Ed. Timpul, Iaşi.

7. Gardner, H., (1990), Art education and human development, CA: Getty Center for Educationin the Arts, Los Angeles.

8. Hadârcă, M., (2014), Educaţia integrală şi curriculum integrat, în „Eficientizarea învăţământului - vector al politicilor educaţionale moderne", Materialele Conferinţei Ştiinţifice Internaţionale 11-12 decembrie, 2014, Chişinău.

9. Ionescu, M., Radu, I., (2001), Didactica modernă, Editura Dacia, Cluj-Napoca.

10. Kant, I., (2007), Critica facultăţii de judecare, ALL, Bucureşti.

11. Piaget, J., (1985), The equilibration of cognitive structures: the central problem in intellectual development, Universityof ChicagoPress, Chicago.

12. Polich, J., (1982), Hemispheric differences for vissual search: Serial vs. Parallel Processing Revisiteol „Neuropsychologia, vol. 2, N. 3.

13. Smuts, J., (1926), Holism and Evolution, New York. 